\section{Irena Čelić ${ }^{1}$}

University of Kragujevac

Faculty of Hotel Management and Tourism in Vrnjačka Banja
P. 21-28

SCIENTIFIC REVIEW ARTICLE doi:10.5937/ESD1902021C

Received: September, 14, 2019

Accepted: October, 12, 2019

\title{
THE CORPORATE SOCIAL RESPONSIBILITY IN SERBIAN HOSPITALITY INDUSTRY ${ }^{2}$
}

\begin{abstract}
One of the characteristics of business in the 21st century is the use of the corporate social responsibility (CSR) concept. The modern trends in the hospitality industry condition the firms to maintain a competitive advantage in the market by applying the CSR. The firms can use the CSR concept through different dimensions. Ecological, social and employee protection dimensions are most common among them. The firms can come across certain hurdles while realizing the CSR. On the other hand, they can achieve some advantages for the internal and external environment of the enterprise. The aim of this paper is to determine whether Serbia has a small number of hotels which use the CSR concept.
\end{abstract}

Key words: social responsibility, hospitality industry, firms, Serbia.

JEL classification: M14, Z32

\section{ДРУШТВЕНО ОДГОВОРНО ПОСЛОВАЊЕ ПРЕДУЗЕКА У ХОТЕЛСКОЈ ИНДУСТРИЈИ СРБИЈЕ}

\begin{abstract}
Апстракт
Једна од карактеристика послована предузећа у 21. веку јесте примена кониепта друштвено одговорног послована (ДОП). Савремене тендениије у хотелској индустрији условљавају предузећа да кроз примену концепта ДОП-а одрже конкурентску предност на тржишту. Примену кониепта ДОП-а предузећа могу остварити кроз различите димензије. Најчешће су то еколошка, соиијална и димензија заштита запослених. Током реализације ДОП-а се може наићи на одређене баријере. Са друге стране, могу се остварити и одређене користи за интерно и екстерно окруженье предузећа. Цит овог рада јесте утврдити да ли хотели у Србији применују кониепт друштвено одговорног послована.
\end{abstract}

Клучне речи: друштвана одговорност, хотелијерска индустрија, предузећа, Србијаи

\footnotetext{
${ }^{1}$ irena.celic994@gmail.com

${ }^{2}$ The paper is a result of research within the project 179066, funded by the Ministry of Education, Science and Technological Development of the Republic of Serbia.
} 


\section{Introduction}

The firms often encounter numerous challenges on the market. The solutions for them have to be in accordance with the principles of ethics, economy, and law. Apart from producing revenue, the companies are expected to take care of the environment, employees, and local communities (Cramer, 2017). Today, the competition is ruthless and it's difficult to sustain in the market. The companies should accept the CSR concept in order to increase the competitiveness and have dedicated and engaged employees (Zientara et al., 2015). In his paper, Ciriković (2012) points out that the use of the CSR leads to a better competitive position of the company both on the national and international market which creates an efficient and effective business.

The social responsible behavior brings benefits not only to the company, but also to the community. There are numerous examples of the firms in the hospitality industry which are socially responsible. This has helped them sustain and become leaders on the market. Abram \& Jarzabek (2016) write that the hotels that implement the CSR concepts will not solve the social macro problems such as unemployment, poverty, social exclusion and demography. However, they can contribute to the reduction of problems on the local scale. Such an approach is consistent with the statement "Think globally, act locally".

Certain corporations have created their own dedicated organizational units to effectively manage their social obligations. (Wang et al., 2016). Leipziger (2017) indicates that the investors and management of a company have to realize that the corporate management, social and ecological results are the important elements of the sustainable financial profitability. So, the CRS is a chance for the firm to achieve the adequate gain through the positive impact on the environment.

However, there are companies which are not sufficiently engaged in the CRS concept. They don't even show whether they are dedicated to the implementation of the social responsibility concept. In his paper, De Grosbois (2012) states that, even though a large number of companies report commitment to CSR goals, much smaller number of them provide details of specific initiatives undertaken to contribute to these goals and even less of them report actual performance achieved in the field of the CSR.

On the other hand, numerous hurdles can influence the insufficient implementation of the CSR. The results of the Bello et al. (2017) research show that the major barriers to the implementation of the CSR are the financial restrictions and the lack of interest and understanding of the CSR by the higher management. Given that the companies are extremely sensitive to the financial aspect of business, this can present a major barrier in the introduction of the CSR

Many companies try to respect the CSR concept. However, there are those that only focus on gaining profit without regard to the community, ecological and social issues. The aim of the paper is to determine whether the hotels in Serbia implement the CSR concept.

\section{Corporate social responsibility and sustainability of hotels}

The social responsibility is the company's realization that equal chances for all, equality, racial equality, workplace equality, appropriate work conditions, harmless products and services exist (Vuković \& Voza, 2016).

According to Atanacković (2011) the corporate social responsibility (CSR) is a concept within which the companies willingly integrate social and environmental 
challenges into their business. The CRS is characterized by the strategy of the ethics and sustainability management (Sekulić \& Pavlović, 2018). When talking about the hotels, numerous factors can exert influence on their strategy of the CSR. Calveras (2015) states that the factors can be the economies of scope and the internal organization of the hotel.

The company has a chance to show its social responsible behavior in different fields. According to the ISO 26000 standard, there are seven major principles of the social responsibility: organizational governance, human rights, labor practices, the environment, fair operating practices, consumer issues, community involvement and development (Image 1).

\section{Image 1: Seven main principles of social responsibility}

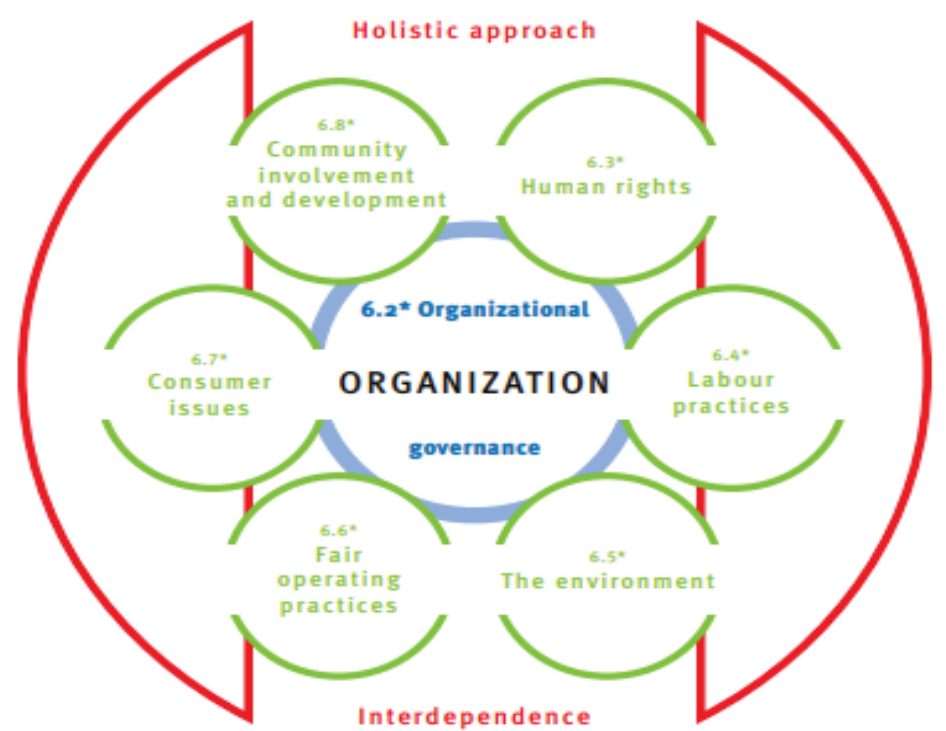

Source: International Organization for Standardization. ISO 26000 and the International Integrated Reporting Framework briefing summary, available at: https://www.iso.org/files/live/sites/isoorg/files/ store/en/PUB100402.pdf )

According to Jovanović (2017), the CSR is the important indication of the corporate sustainability and sustainable development. Szczuka (2015) states that the CSR is a response of the economic sector to the sustainability challenges.

Gaweł et al. (2015) say that the benefits of the CSR implementation are visible within the company and in its external environment. According to these authors, they include:

1. Financing environmental protection,

2. Creating new jobs,

3. Lowering prices of products,

4. Improving product's quality,

5. Complying with legal regulations, 


\section{Fair competition,}

7. Improving communication,

8. Reducing pollution.

The sustainable business can help the hospitality industry to obtain the benefits. Vujošević \& Krstić-Furundžić (2015) write that, by following the sustainable business, the following subjects can benefit:

1. The management and employees of the hotel by achieving results,

2. The guests by providing the high level of service,

3. Environment by decreasing the negative impact on it.

The CSR is the factor of the sustainable business promotion (Milić, 2017). As such, it exerts a positive impact on the specific aspects of business, shown in Table 1.

Table 1: The positive influence of CRS

\begin{tabular}{|c|c|}
\hline \multirow{4}{*}{ CSR } & Competitive Advantage \\
\cline { 2 - 3 } & Reputation \\
\cline { 2 - 3 } & The ability to attract and retain the employees, buyers, clients, or users \\
\cline { 2 - 3 } & Maintaining employees' morale, dedication, and productivity \\
\cline { 2 - 3 } & The attitude of the investors, owners, donors, sponsors, and financial community \\
\cline { 2 - 3 } & $\begin{array}{c}\text { The relation with the companies, governments, media, suppliers, colleagues, users, and } \\
\text { community within which one works }\end{array}$ \\
\cline { 2 - 3 } & Preservation of the natural resources and energy efficiency \\
\hline
\end{tabular}

Source: The author's presentation according to Milić, Z. (2017)

An empirical study of Benavides-Velasco et al. (2014) in the Spanish hotels of the Andalusian region shows that the adoption of the CSR improves the capacity of hotels to create benefits for their stakeholders. These results then have a positive effect on hotel performance.

Tolušić et al., (2014) think that the company which takes care of the economic, social, and ecological impact is successful in the CSR. Also, Vuković \& Voza (2016) say that the CSR concept means that one company should achieve its business goals and expectations of the owner. In addition, it should balance the economic, ecological, and social imperatives. Quien (2012) believes that the CSR is produced as a response of the way a community, region, and society perceive the social issue. The idea is that the organization is not only focused on its work, but it considers the entire context, i.e. the community within which it operates.

\section{The Forms and Dimensions of the Social Responsibility}

Salarić \& Jergović (2012) say that the CSR exists both inside and outside the company. The CSR inside the company refers to the areas such as: investing in human capital, health and safety, managing changes and natural resources used in the production. On the other hand, the CSR outside the company entails: the local community, business partners and suppliers, consumers, government, local associations, etc. 
The companies through their sustainable development have a chance to show they are socially responsible in numerous dimensions. According to Jovanović (2017), aside from the economic and legal dimensions, the following responsibilities are important to the company's business: ethical and philanthropic. According to Ivanović \& Krstic (2017), the basic dimensions of the social responsibility are:

1. Ecological responsibility - emphasizes the major social responsibility of the company regarding the sustainable development and sustainable economy in terms of protection and preservation of the healthy environment.

2. Social responsibility - stresses the company's responsibility to participate in the resolution of different social issues.

3. Employees' health and workplace safety - encourages the managers and employees to decrease the risks (accidents and injuries at the workplace). Also, it teaches them to realize or improve the existing programs that make sure employees' preserve their health and are safe at the workplace.

4. Ethical behavior - refers to the behavior that follows the principles of the social moral and ethical norms.

Today, a company has to create an environment where it can use one of the three corporate social opportunities. Grayson \& Hodges (2017) refer to these corporate social opportunities as commercially viable activities, which also advance environmental and social sustainability. According to these authors, the social opportunities are based on:

1. Innovations in developing new or improved products and services,

2. Organizing the business differently in a new business model,

3. Serving under-served or creating new markets.

\section{Social Responsibility of Hotels in Serbia}

The implementation of the CSR concept is a characteristic of the developed countries. In Serbia, this concept is used in numerous industries. Regarding the hospitality industry, Milovanović (2014) thinks that the pioneers in the CSR implementation are those hotels which are a part of the international hotel chains.

Grayson \& Hodges (2017) stress that about 2,000 international companies regularly report on their impact on the environment and society. Also, the same authors write that in some countries (e.g. France, Australia) it is mandatory to publish reports. The understanding of the CSR in Serbia is insufficient and it requires increased education and motivation of the owners, managers, and employees in tourism and hospitality (Stojanović-Aleksić \& Bošković, 2016). Milovanović (2014) and Kicošev et al. (2017) in their papers stress that the social responsibility isn't sufficiently represented in the hospitality industry in the Republic of Serbia.

There are hotels which operate in Serbia and serve as an example of how to behave socially responsible. Milovanović (2014) mentiones the following programs of the social responsibility of hotels in Serbia:

- The hotel chain InterContinental (IHG) implemented the Green Engage system in 2009. The system is for the evaluation, management, and reports in order to efficiently use the energy an water, decrease waste and the negative 
impact of it on the environment and community. The results of this program are manifested in the energy reduction of $25 \%$.

- Hotel Palace received an award for educating students, many of whom work in the prestigious national and international hotels as managers. Hotel Palace employes the best candidates.

- Hotel Hyatt Regency in Belgrade has reduced energy use by $20 \%$ thanks to the new technologies. The hotel has also introduced the paper recycling program. The hotel's cleaning department uses microfiber-based cloths which don't require them to use a lot of cleaning products. At the same time, they use the aerosol chemicals, thus reducing the pollution.

Also, certain local hotels in Serbia implement the CSR. They usually do that by improving the employee and client satisfaction and providing education in the field of hospitality (Mandarić \& Milovanović, 2016).

Ivanović-Đukić (2011) concludes that the hotel management in Serbia has to realize that the CSR is a strategic priority. It is not a temporary activity which attracts the attention of the public and secures a free promotion. Her conclusion can be a basis for the introduction of the CSR in the international and national hotels in Serbia.

Therefore, we can see that the CSR is implemented in the hotels in Serbia. However, the level of implementation remains low and it is more visible in those hotels which are a part of the international hotel chains.

\section{Conclusion}

The imperative for the successful business of a company is to apply the CSR. The CSR, as a business strategy, is the concept which helps one company be recognizable in the market.

The CSR is an important part of the sustainable business. The CSR relies on the three basic dimensions of sustainability, i.e. economic, social, and ecological. The company achieves its social responsibility on a local and global scale by implementing the concept in these dimensions.

If a hotel supports the CSR concept, it can achieve the concept through internal and external business. In this way, it will gain benefits for the employees, managers, stakeholders, local community, country, and nature, etc. The path to implementing this concept isn't by any means an easy one. The hotel has to overcome numerous barriers. As the major barriers, authors stress finance and the disinterest of managers in the implementation of the CSR.

The fact is that the state of the hospitality industry in Serbia is improving. There are attempts to modernize the hotel business in different destinations. Certain hotels in Serbia already use the CSR concept. These are usually the venues which are a part of the hotel chains. A small number of local hotels also implement the concept. In the end, we can conclude that the CSR is not sufficiently developed in the hospitality industry in Serbia.

In order to achieve the desired effects, the hospitality industry in Serbia should perceive the CSR as a chance for improvement. The CSR has to be an activity which will be 
carried out in the companies all the time. This is a concept which should be implemented in the business strategy of the hotels in Serbia.

\section{References}

Abram, M., \& Jarzabek, J. (2016). Corporate social responsibility in hotel industry environmental implications. Ecocycles, 2 (2), 9-16.

Atanacković, U. (2011). Društveno odgovorno poslovanje kao savremeni koncept biznisa. Škola biznisa, 1, 143-148.

Bello, F. G., Banda, W. J., \& Kamanga, G. (2017). Corporate Social Responsibility (CSR) practices in the hospitality industry in Malawi. African Journal of Hospitality, Tourism and Leisure, 6 (3), 1-21.

Benavides-Velasco, C. A., Quintana-García, C., \& Marchante-Lara, M. (2014). Total quality management, corporate social responsibility and performance in the hotel industry. International Journal of Hospitality Management, 41, 77-87.

Calveras, A. (2015). Corporate social responsibility strategy in the hotel industry: Evidence from the Balearic Islands. International Journal of Tourism Research, 17 (4), 399-408.

Ciriković, E. (2012). Značaj korporativne društvene odgovornosti za savremeno poslovanje. In BH ekonomski forum (No. 4, pp. 135-146). Ekonomski fakultetUniverzitet u Zenici.

Cramer, J. (2017). Corporate Social Responsibility and Globalisation: an action plan for business. London \& New York, Routledge.

De Grosbois, D. (2012). Corporate social responsibility reporting by the global hotel industry: Commitment, initiatives and performance. International Journal of Hospitality Management, 31 (3), 896-905.

Gaweł, E., Jałoszyńska, A., Orłowski, M., Ratajczak, E., Ratajczak, J., \& Riera, B. (2015). Corporate social responsibility as an instrument of sustainable development of production enterprises. Management Systems in Production Engineering. 19 (3), 152-155

Grayson, D., \& Hodges, A. (2017). Corporate social opportunity!: Seven steps to make corporate social responsibility work for your business. London \& New York, Routledge.

International Organization for Standardization. ISO 26000 and the International Integrated Reporting Framework briefing summary, available at: https://www.iso. org/files/live/sites/isoorg/files/store/en/PUB100402.pdf (11. Oktober 2019.)

Ivanović-Đukić, M. (2011). Promovisanje društveno odgovornog poslovanja preduzeća u Srbiji. Sociologija, 53 (1), 21-42.

Jovanović, M. (2017). Korporativna društvena odgovornost kao determinanta održivosti. Economics of Sustainable Development, 1 (1), 93-107.

Kicošev, S., Blešić, I., \& Bradić, M. (2011). Are successful financial companies in Serbian hotel industry also socially responsible?. Economic Themes, 49 (2), 289-301.

Leipziger, D. (2017). The corporate responsibility code book. New York, Routledge. 
Mandarić, M., \& Milovanović, V. (2016). The Role of CSR in the Development of Sustainable Tourism in Serbia. In TISC-Tourism International Scientific Conference Vrnjačka Banja (Vol. 1, No. 2, pp. 412-429).

Milić, Z. (2017). Društveno odgovorno poslovanje u hotelskoj industriji kao factor unapređenja održivog razvoja Crne Gore. FBIM Transactions, 5 (1), 74-79.

Milovanović, V. (2014). Corporate social responsibility of hotels in Serbia as an element of total quality management. Ekonomija: teorija i praksa, 7 (2), 61-73.

Quien, M. (2012). Društveno odgovorno poslovanje kao konkurentna prednost: analiza ciljeva najuspješnijih tvrtki u Hrvatskoj. Učenje za poduzetništvo, 2 (1), 303-307.

Radović, G., Košić, K., \& Demirović, D. (2018). Financing as a key factor of the strategy of sustainable rural tourism development in the Republic of Serbia. Ekonomika poljoprivrede, 65(1), 413-426.

Salarić, D., \& Jergović, A. (2012). Poduzetništvo i društveno odgovorno poslovanje. Učenje za poduzetništvo, 2 (2), 295-301.

Sekulić, V., \& Pavlović, M. (2018). Corporate social responsibility in relations with social community: Determinants, development, management aspects. Ekonomika, 64 (4), 59-69.

Stojanović-Aleksić, V., \& Bošković, (2016). A corporate social responsibility in tourism and hospitality: Empirical study from Serbia. Contemporary issues in economics, business and management, 57-66. 4 th International Scientific Conference, Faculty of Economics University of Kragujevac, Kragujevac, The Republic of Serbia.

Szczuka, M. (2015). Social dimension of sustainability in CSR standards. Procedia Manufacturing, 3, 4800-4807.

Tolušić, Z., Dumančić, E., \& Bogdan, K. (2014). Društveno odgovorno poslovanje i zeleni marketing. Agroeconomia Croatica, 4 (1), 25-31.

Vujić, M., Đorđević, S., \& Lakićević, M. (2019). Service quality and customer satisfaction in the hotel industry in Serbia. Menadžment u hotelijerstvu i turizmu, 7(1), 61-70.

Vujošević, M., \& Krstić-Furundžić, A. (2015). Zaštita životne sredine i hotelski objekti. U: Deveto naučno-stručno savetovanje” Ocena stanja, održavanje i sanacija građevinskih objekata i naselja”, Beograd.

Vuković, M., \& Voza, D. (2016). Koncept društvene odgovornosti u hotelijerstvu sa težištem na ekološkim performansama. International Thematic Monograph Thematic Proceedings: Modern Management Tools and Economy of Tourism Sector in Present Era. Udekom Balkan.

Wang, H., Tong, L., Takeuchi, R., \& George, G. (2016). Corporate social responsibility: An overview and new research directions: Thematic issue on corporate social responsibility. Academy of Management Journal, Vol. 59 (2), 534-544.

Zientara, P., Kujawski, L., \& Bohdanowicz-Godfrey, P. (2015). Corporate social responsibility and employee attitudes: evidence from a study of Polish hotel employees. Journal of Sustainable Tourism, 23 (6), 859-880.

Ivanović, V., \& Krstić, B. (2017). Dimenzije održivog razvoja i društvene odgvornosti preduzeća u konceptu balansne karte performansi. Economics of Sustainable Development, 1 (2), 85-107. 